\title{
E3 Ubiquitin-Protein Ligase RING2
}

National Cancer Institute

\section{Source}

National Cancer Institute. E3 Ubiquitin-Protein Ligase RING2. NCI Thesaurus. Code C150306.

E3 ubiquitin-protein ligase RING2 (336 aa, $\sim 38 \mathrm{kDa}$ ) is encoded by the human RNF2 gene. This protein is involved in both transcriptional repression and the monoubiquitination of lysine-119 of histone H2A. 